\title{
Analysis of ticket price in the airline industry from the perspective of operating costs, supply and demand
}

\section{Preços de passagens aéreas analisados sob a perspectiva dos custos operacionais, oferta e demanda}

\author{
Udinelli Alves ${ }^{1}$, Mauro Caetano² \\ ${ }^{1}$ Master Student. Administration Postgraduate Program (PPGADM/FACE) at Federal University of Goiás (UFG).<udinellialves@gmail.com> \\ 2 Postdoctoral in Aeronautics Infrastructure Engineering (Aeronautics Institute of Technology - ITA), Production Engineering, Ph.D (University of São Paulo - USP), \\ Professor/Researcher at Administration Postgraduate Program (PPGADM/FACE) and Agribusiness Postgraduate Program (PPAGRO/EA) \\ at Federal University of Goiás (UFG). <maurocaetano1912@gmail.com>
}

\begin{abstract}
This study provides an analysis of airline ticket price and its determinants, such as operating costs, supply and demand. The research aimed to establish the relationship between ticket price and these influencing variables, using a correlation method to verify their effect. A linear regression model was developed using the least squares method to explain whether a causal relationship exists between the variables. The results show that, although a relationship does exist between airline ticket price and operating costs, it is overshadowed by the fact that the main determinant of pricing is explained by the relationship between supply and demand.
\end{abstract}

KEYWORDS: airline industry; costs; demand; pricing.

\section{RESUMO}

Este estudo fornece uma análise do preço do bilhete de avião e seus determinantes, tais como os custos operacionais, a oferta e a demanda. O objetivo desta pesquisa consiste em determinar qual é a relação entre o preço do bilhete, o que a determina e qual destas variáveis a afetam, usando um método de correlação. Um modelo de regressão linear foi elaborado usando o método dos mínimos quadrados para explicar se existe uma relação causal entre as variáveis. Os resultados mostram que, apesar de existir uma relação entre o custo dos bilhetes de avião e os custos operacionais, essa relação é ofuscada devido ao fato de que o principal determinante do preço do bilhete é explicado pela relação entre a oferta e a demanda.

PALAVRAS-CHAVE: indústria aérea; custos; demanda; preço.

Pontifical Catholic University of Rio Grande do Sul Porto Alegre, RS, Brazil

Editor

Thaís Russomano

Microgravity Centre PUCRS, Brazil

Executive Editor

Rafael Reimann Baptista

Faculdade de Educação Física e Ciências do Desporto, PUCRS, Brazil

e-ISSN: 2179-703X
Corresponding Author:

Udinelli Alves

<udinellialves@gmail.com>

Received: February 02, 2016 Accepted: March 12, 2016

(c) 2016 EDIPUCRS 


\section{Introduction}

Demand for civil aviation services has shown continued and significant growth over the last few years. Passenger air transportation in Brazil has increased by $168 \%$ in the period from 2004 to 2013. A total of 19.2 million international and 90 million domestic passengers were recorded in 2013, an increase of $110 \%$ and $181 \%$, respectively, in comparison to 2004 (ANAC, 2014).

Even with growing demand, the Brazilian airline industry has accumulated successive losses of approximately USD 602 million in 2011, USD 1310 million in 2012 and USD 908 million in 2013 (ANAC, 2014). The airlines seek to focus on cost reductions to solve the conditions of continuing losses that this sector holds.

Many studies have attempted to understand how costs can affect airline companies and, consequently, their competitiveness (Vasigh et al., 2008; Kun et al., 2014; Wen-Cheng, 2012; Zuidberg, 2014; Siew and Yongtao, 2014; Alamdari and Morrel, 1997; Tae and Chunyan, 1998). However, most of these studies have ignored the relationship between costs, profitability, aircraft utilization and prices of air transport tickets. Supply and demand have a direct impact on airline ticket price. These variables determine how price is affected by the quantity of product on offer and how the market demands the product over its price and utility (Vasconcelos, 2002).

The pricing of products and services in relation to costs can be baffling, which can be explained by the definition of contribution margin and net profit. As explained by Dias (1992), contribution margin represents the value that covers the fixed costs and provides profit. The contribution margin can be obtained by deducting the variable costs from the selling price. Net profit can be identified by deducting the fixed costs from the contribution margin. The airline industry is a highly competitive sector, and therefore it is necessary to analyze price and costs together.

Ticket price depends on a complete analysis of costs, supply and demand. Costs form the base for the profit margin of a business, and are consequently one of the main determinants of price. Supply and demand reflect the behavior of the consumer and market, providing information on how the price is formed from quantity and utility of the services offered by the airline industry.

The focus of this study aimed to analyze the behavior of airline ticket prices in relation to variables, such as costs of fuel, labor and maintenance, and supply and demand. It also sought to offer an overview of the Brazilian airline industry as a whole in terms of costs, supply and demand. To this end, Brazilian airline industry data from 2004 to 2013 was gathered in order to observe the costs of fuel, labor, supply, demand, total cost and profit/loss. Data from the Brazilian National Civil Aviation Agency (ANAC) was analyzed from an econometric perspective through a simple linear regression model using the least squares method, to explain whether a causal relationship exists between the variables. The software ActionR was used, integrated with Microsoft Excel. The average exchange rate value from the first semester of 2015 was used for calculations, with 1 USD being equivalent to $2.643 \mathrm{BRL}$.

\section{Air transportation operating costs}

Strong competition between airline companies has brought about a new reality for the sector. Seeking to become more competitive, the reduction of operating costs has become an accepted practice leading to greater profitability and giving a competitive advantage to airlines. The management of costs is an integral part of the strategic decision making process of airlines, since knowledge of costs is an essential element in identifying if a product or service at a given price is profitable or not.

Approximately $60 \%$ of the costs in air transportation are concentrated in fuel and human resources (Kun et al. 2014). In Brazil, fuel, labor and maintenance (plus lease and insurance) expenses correspond to 63.9\% of total costs (ANAC, 2014). Although forming a significant portion of the cost, these variables alone cannot explain the totality of costs. The main incurred costs of an airline operation include those related to fuel, labor, depreciation of flight equipment, maintenance (plus lease and insurance), airport fees, air navigation charges, indirect costs, general administrative expenses and other operating overheads. Table 1 shows the percentage of each of these expenses in the Brazilian airline industry.

Table 1. Distribution of operating expenses in 2013

\begin{tabular}{lc}
\hline \multicolumn{1}{c}{ Expense item } & Percent \\
Fuel & $37.30 \%$ \\
Maintenance, lease and insurance & $16.96 \%$ \\
Labor & $9.64 \%$ \\
Indirect costs & $8.80 \%$ \\
Administrative expenses & $7.28 \%$ \\
Depreciation & $3.70 \%$ \\
Air navigation charges & $3.42 \%$ \\
Airport fees & $2.53 \%$ \\
Other operating expenses & $10.36 \%$ \\
Total & $100 \%$ \\
\hline
\end{tabular}

Source: ANAC (2014). 
According to ANAC (2014), the Brazilian airline industry recorded costs and expenses of USD 12.03 billion in 2013, with this being a 6.1\% increase on the previous year. The average yearly rise in costs and expenses was 15.3\% between 2009 and 2013. The air industry involves activities that transport people and goods, therefore cost management must be considered not only for the reduction of costs, but also as a technique for applying innovation and technology that satisfies an efficient distribution of costs to provide safety and quality to consumers, thus fulfilling not only profitable results but accomplishing its social service worldwide.

One of the tools measuring efficiency over costs in air transportation is CASM (Cost per Available Seat Miles), consisting of a system that measures the costs incurred by an airline to fly an available seat one mile (Vasigh et al., 2008). These authors define that total CASM is calculated over direct operating costs, such as fuel, labor and maintenance, and considers fixed costs and general expenditures.

A major operating expense for airline companies is fuel costs, which increased more than $271 \%$ in the period from 2004 to 2013, as shown in Figure 1. This constitutes one of the most important items in the decision making process for airlines through its being the largest operating cost. Fuel has a great impact on the airline CASM and to manage this resource some airlines employ diverse strategies, one of which relates to derivatives known as fuel hedging.

Figure 1. Fuel expenses (USD billion)

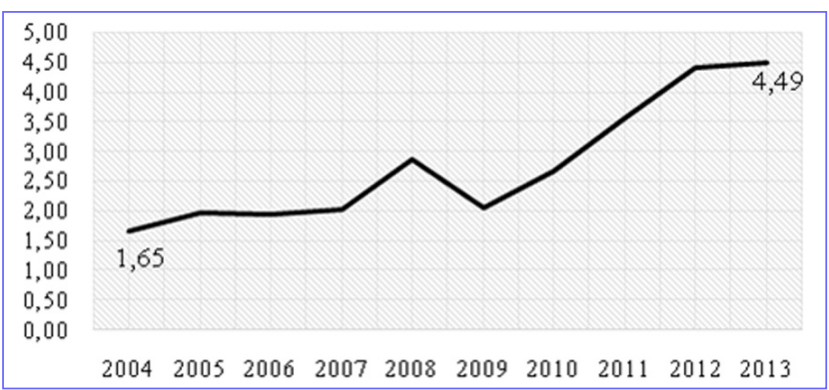

Source: ANAC (2014).

Fuel hedging helps airline companies manage the possible variations in fuel supply by trying to mitigate against the risk of an uncontrollable increase in price (Siew and Yongtao, 2014). Managing fuel costs is difficult since it is a monopolized market where decision-making related to pricing and distribution is concentrated in the hands of the Organization of the Petroleum Exporting Countries (OPEC). Some of the participating countries have huge oil reserves and thus exert control over oil supply, such as Saudi Arabia, the largest oil producer worldwide (Difiglio, 2014).
The variations in fuel expenses presented in Figure 1 show successive increases in this cost, which nearly tripled in value over the period from 2004 to 2013. Fuel price is controlled by the oil monopoly, leaving little flexibility in the decision-making processes linked to this expense and intensifying the need for airlines to develop strategies to better cope with the remaining costs (IATA, 2006).

Maintenance represents the second largest expense in the Brazilian aviation industry and can be considered as an investment in aircraft and passenger safety. Most airlines adopt outsourced maintenance services. Maintenance costs are related to engine inspections and servicing, rotor checks, propeller and pressurization systems, air conditioning, and navigation aids, among others. The factors having the greatest influence on these maintenance costs relate to the age, quality and diversity of the airline fleet. Having a variety of aircraft requires a multiplicity of airplane parts and specialized maintenance, hence requiring more expenditure (Vasigh et al., 2008).

The third largest operating costs expense is labor, constituting one of the areas most affected by the need for cost reduction, as airline companies possess more control over this variable. Typical measures employed to reduce this cost include staff dismissals, wage cuts, work outsourcing, the use of cheaper labor abroad, franchising, and so on (Alamdari and Morrel, 1997).

Operating costs and expenses, however, are not the only factors that explain price and profit behavior. The law of supply and demand is also relevant to clarify such behavior since it explains how variations in market affect these.

\section{Supply and demand}

Supply and demand are two economic variables that help to define market costs and prices. Demand represents the search for a product or service due to the necessity or desire of a consumer and supply represents the availability of this product or service in the market.

The factors most affecting demand in air transportation are ticket price, competitor ticket price, passenger income, availability of other transport modes, consumer loyalty, frequency of service, and state of the economy, together with other random factors (Vasigh et al., 2008). Ticket price is the factor noted as having the most influence on demand. An increase in airline ticket cost affects the consumer's sensitivity to price, resulting in a demand for the services of other airlines or other modes of available transportation, such as rail, ship or road transport. 
A competitor's price represents a comparison factor. If an airline has a lower ticket price for the same route, demand for their services will increase, whereas the opposite will occur if the ticket price is higher.

The availability of other modes of transportation signifies alternative possibilities of locomotion, thus bringing more competition into the transport sector. In theory, this greater choice of transport modes will tend to reduce demand because the consumer will have a wider option to choose which product or service will satisfy their needs.

The income of passengers reflects on how much they are willing to pay for a product or service. A rise in passenger income will increase the demand for the airline products and services, while a decrease will tend to cause a demand for substitute services. Consumer loyalty motivates the client to continue consuming the service or product and dissuades them from avoiding the brand.

Random factors can be considered as noncontrollable events that may affect the industry, such as the terrorist attacks of September 11 $1^{\text {th }}$ 2001, which negatively affected the demand for air transport services due to the perceived insecurity related to airports and aircrafts (Vasigh et al., 2008).

The demand for air transportation in Brazil increased by $165 \%$ in the period between 2004 and 2013 (ANAC, 2014), as shown in Figure 2.

Figure 2. Number of passengers (million) using the Brazilian airline industry

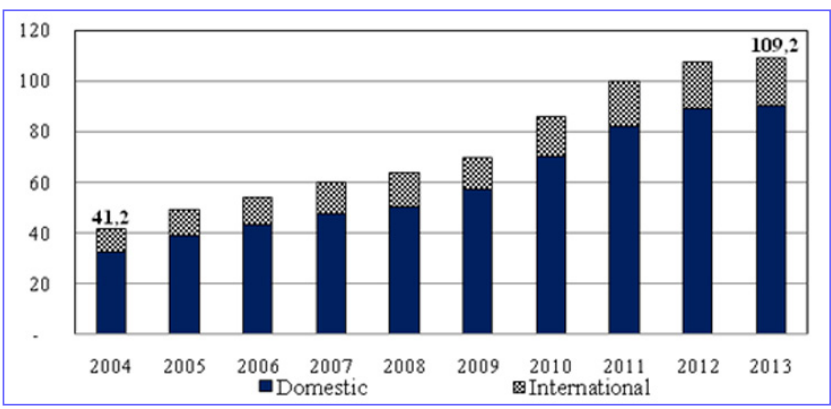

Source: ANAC (2014).

According to Figure 2, demand in both the domestic and international flight markets grew constantly from 2004 to 2013 , increasing by $181 \%$ in the domestic and $110 \%$ in the international markets.

A decrease in average ticket price was recorded during this period, correcting for the effect of inflation using the Brazilian National Consumer Price Index (Índice de Preços ao Consumidor Amplo, IPCA), which can be observed in Figure 3. The average ticket price represents the average value paid per passenger on air travel. This decrease in ticket price could explain the growing demand and its variations.

Figure 3. Average ticket price (USD)

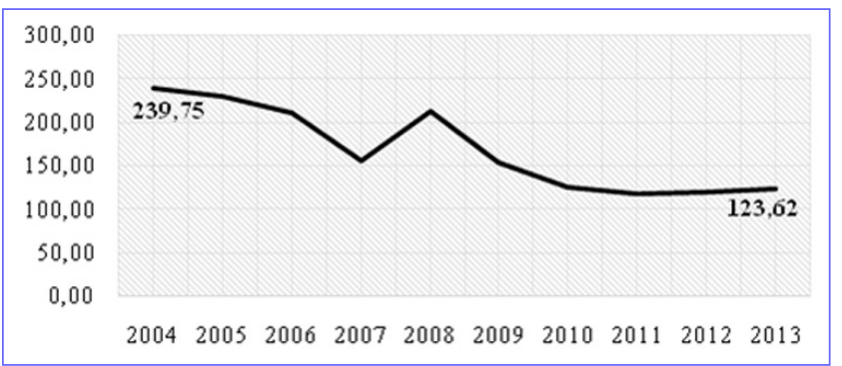

Source: ANAC, 2014

At the same time, during this period from 2004 to 2013 , constant increases in supply were recorded. According to ANAC (2014), 1,087 million flights were registered in Brazil in 2013, an increase of $81 \%$ on 2004. The relationship between supply and demand was the main reason successive decreases in ticket prices were made possible.

The observation of costs and study of market structure using the law of supply and demand brings a general view of how price is formed, but another factor is also relevant to investigation of price formation, which is competitiveness.

\section{Competitiveness in air transportation}

The airline industry experienced many structural changes in the mid-1980s. Several countries deregulated their laws related to air transportation and signed a number of bilateral agreements (Tae and Chunyan, 1998). An example of one such deregulation can be identified in the US Airline Deregulation Act of 1978, which was intended to decrease government control over the airline industry. This act affected air transportation on a global scale. New airlines emerged and the fresh investments made affected the competitiveness in this sector (Vasigh et al., 2008).

Research presented by Zuidberg (2014) points out that airline profit has drastically decreased in recent years, mainly with the emergence of low-cost carriers. High costs and the practice of lower ticket prices have put in jeopardy the survival of airlines around the world.

Data from IATA (2006) reveals the intense search for cost reduction represents a competitive edge for airlines. Companies that fail to apply policies focused on cost restriction are bound to fail. Tae and Chunyan (1998) explain that the liberalization 
agreement between countries expanded boundaries and thus, intensified competition between airlines, which must now compete at an international level. Wen-Cheng (2012) demonstrates that large airlines need to reformulate their costs strategies to improve performance. Most of these companies could reduce their inputs, such as fuel, labor and fleet costs, while keeping their outputs at the same standard, which are the services required to take a passenger from one point to another, thereby improving efficiency ratios. The same author points out that the passenger load factor constitutes one of the variables that most influences the financial performance of an airline and is an area requiring further enhancement and research.

The need for greater competitiveness has intensified and the continued success and survival of an airline depends on efficient cost management. An airline is cost efficient if its unit cost is lower than that of its competitors. The CASM represents a comparison between airlines; a company is more competitive the lower the CASM (Tae and Chunyan, 1998). With an efficient CASM, prices can be more attractive bringing more clients and increasing revenue and profit.

The policies established by Brazilian Law $11.182 / 2005$, which deals with freedom in relation to ticket price and supply, has led to greater openness to free competition and encouraged development within the industry, such as incentives to innovate, supply compatible with demand, optimization of costs management and more efficiency in general, leading to better competitiveness (ANAC, 2015).

The Brazilian airline industry registered successive financial losses, presenting a poor economic-financial performance, but showed increases in supply and demand. Available Seat-Kilometers (ASK) represents the supply variable an is obtained through the total quantity of seats offered multiplied by the distance in kilometers, i.e., one ASK is equivalent to one available seat multiplied by one kilometer flown. Revenue Passenger-Kilometers (RPK) is a measure of the quantity of paying passengers carried by an airline by distance flown and represents the demand (ICAO, 2004). Both variables presented increased between 2004 and 2013, showing great growth mainly on the demand side, which increased at a greater rate than supply. Operating costs were also subject to rises, with fuel costs having major impact on total costs, reflecting in a poorer financial performance. The sector faces great challenges with elevated costs and successive losses confirming that its competitiveness is affected in a global market.

\section{Results}

The result analysis is displayed in Table 2, presenting data for the Brazilian airline industry from 2004 to 2013. It contemplates average ticket price in USD, corrected for the effect of inflation using the IPCA, and fuel, maintenance, labor and total costs (USD billion). Further elements relate to supply (ASK), demand (RPK) and profit/loss (USD million). The ASK and RPK variables were associated in order to identify any possible relationship between supply and demand. ASK-RPK represents the lack of capacity utilization of the available seats, while Passenger Load Factor (PLF) represents the percentage of seats utilization.

A constant decrease in average ticket price can be observed from Table 2, while costs followed a tendency to increase. In relation to the ASK and RPK, both maintained a constant increase, although the growth of RPK was superior to ASK, thus denoting an improved PLF. The value for ASK-RPK represents a relative measure, which in this study refers to the unused quantity of supply (i.e., represents the ASK that did

Table 2. Data from the Brazilian airline industry

\begin{tabular}{rccccccccccc}
\hline Year & $\begin{array}{c}\text { Average } \\
\text { ticket price } \\
\text { (USD) }\end{array}$ & $\begin{array}{c}\text { Fuel } \\
\text { (USD billion) }\end{array}$ & $\begin{array}{c}\text { Maintenance } \\
\text { (USD billion) }\end{array}$ & $\begin{array}{c}\text { Labor } \\
\text { (USD billion) }\end{array}$ & $\begin{array}{c}\text { Total Cost } \\
\text { (USD billion) }\end{array}$ & $\begin{array}{c}\text { ASK } \\
\text { (billion) }\end{array}$ & $\begin{array}{c}\text { RPK } \\
\text { (billion) }\end{array}$ & $\begin{array}{c}\text { ASK-RPK } \\
\text { (billion) }\end{array}$ & $\begin{array}{c}\text { PLF } \\
\text { (\%) }\end{array}$ & $\begin{array}{c}\text { Profit or Loss } \\
\text { (USD million) }\end{array}$ \\
\hline 2004 & 239.75 & 1.65 & 1.16 & 0.72 & 5.68 & 44.86 & 29.13 & 15.73 & 64.93 & 43 \\
2005 & 230.60 & 1.98 & 0.95 & 0.84 & 6.01 & 50.51 & 35.10 & 15.42 & 69.48 & -388 & 70 \\
2006 & 210.98 & 1.93 & 0.85 & 0.85 & 5.76 & 57.19 & 40.52 & 16.67 & 70.85 & 259 \\
2007 & 154.53 & 2.03 & 1.02 & 0.90 & 6.06 & 67.46 & 45.74 & 21.73 & 67.79 & -1.082 \\
2008 & 212.97 & 2.87 & 1.07 & 1.14 & 7.58 & 75.37 & 49.71 & 25.66 & 65.95 & -1.102 \\
2009 & 153.70 & 2.05 & 1.34 & 0.80 & 6.81 & 86.29 & 56.85 & 29.44 & 65.88 & 583 \\
2010 & 125.68 & 2.67 & 1.19 & 0.99 & 8.09 & 102.73 & 70.28 & 32.45 & 68.41 & 271 \\
2011 & 117.17 & 3.57 & 1.29 & 1.32 & 9.88 & 116.10 & 81.46 & 34.63 & 70.17 & -602 \\
2012 & 118.14 & 4.40 & 1.60 & 1.30 & 11.34 & 119.34 & 87.05 & 32.29 & 72.94 & -1.310 \\
2013 & 123.62 & 4.49 & 2.04 & 1.16 & 12.03 & 115.91 & 88.24 & 27.67 & 76.13 & -908 \\
\hline
\end{tabular}

Source: Authors, 2015. 
Table 3. Percentage of variation

\begin{tabular}{lcccccccccc}
\hline \multicolumn{1}{c}{ Variable } & $\mathbf{2 0 0 4 - 2 0 0 5}$ & $\mathbf{2 0 0 5 - 2 0 0 6}$ & $\mathbf{2 0 0 6 - 2 0 0 7}$ & $\mathbf{2 0 0 7 - 2 0 0 8}$ & $\mathbf{2 0 0 8 - 2 0 0 9}$ & $\mathbf{2 0 0 9 - 2 0 1 0}$ & $\mathbf{2 0 1 0 - 2 0 1 1}$ & $\mathbf{2 0 1 1 - 2 0 1 2}$ & $\mathbf{2 0 1 2 - 2 0 1 3}$ \\
Price & -3.82 & -8.51 & -26.76 & 37.82 & -27.83 & -18.23 & -6.77 & 0.84 & 4.63 \\
Fuel & 19.52 & -2.54 & 5.39 & 41.20 & -28.48 & 30.44 & 33.48 & 23.24 & 2.04 \\
Maintenance & -18.11 & -10.51 & 20.51 & 4.45 & 25.67 & -11.66 & 8.90 & 23.54 & 27.90 \\
Labor & 15.74 & 1.57 & 6.46 & 25.58 & -29.31 & 23.12 & 33.38 & -1.37 & -10.76 \\
Total cost & 5.91 & -4.18 & 5.17 & 25.16 & -10.14 & 18.69 & 22.26 & 14.78 & 6.06 \\
ASK & 12.61 & 13.21 & 17.97 & 11.72 & 14.49 & 19.05 & 13.01 & 2.79 & -2.87 \\
RPK & 20.49 & 15.45 & 12.88 & 8.69 & 14.36 & 23.63 & 15.91 & 6.86 & 1.37 \\
ASK-RPK & -1.99 & 8.13 & 30.34 & 18.10 & 14.74 & 10.22 & 6.72 & -6.76 & -14.32 \\
PLF & 4.55 & 1.37 & -3.06 & -1.84 & -0.08 & 2.53 & 1.76 & 2.77 & 3.19 \\
Profit/Loss & -1002.76 & 166.73 & -518.06 & -1.82 & 152.94 & -53.46 & -321.84 & -117.45 & 30.69 \\
\hline
\end{tabular}

Source: Authors, 2015.

not generate revenue). This measure shows increases, a fact that indicates a certain idle capacity. Finally, profit/ loss represents the economic-financial performance of this sector, with the data indicating greater losses than profits.

Table 3 demonstrates the percentage variation between years for the variables listed in Table 2 and seeks to facilitate a relationship analysis between the variables through the period. It can be seen that price followed a tendency to decrease, with a significant increase found only in 2008. A contradictory pattern is observed in the comparison of costs and ticket price, with costs constantly increasing while ticket prices mainly decreased. Some year-on-year rises in ticket price were recorded in 2008, 2012 and 2013, with increases of $37.82 \%, 0.84 \%$ and $4.63 \%$, respectively. This suggests there is a paradox between theory and practice, as the greater the variable costs, the greater should be the price of products and services to generate a contribution margin to cover fixed costs and provide profit for the company (Dias, 1992).

The strategy of decreasing ticket prices while costs are rising would seem incoherent, an idea supported by the losses suffered by the airline industry. Six years of losses and four years of profits were registered during the period covered, with the last three years showing losses only. This fact may be explained by two other variables that somehow overshadow the cost/price correlation and show a much stronger relationship with airline ticket price; these variables are supply and demand. A correlation matrix between all variables presented is presented in Table 4. A p-value $\leq 0.05$ was considered significant, while a $\mathrm{p}-$ value $\geq 0.05$ indicated no association between the variables, when adopting 5\% statistical significance (Portal Action, 2015).

The correlation $(r)$ is limited to $-1 \leq r \leq 1$. The closer to the extremes, the stronger is the relationship.
A negative correlation between the variables is expressed when one variable increases as the other related variable decreases, and vice versa. When the relationship is positive, the related variables increase or decrease together, i.e., they follow the same pattern (Gujarati, 2004).

Table 4. Correlation matrix

\begin{tabular}{lcc}
\hline \multicolumn{1}{c}{ Variables } & Price & P - value \\
Fuel & -0.72 & 0.01993 \\
Maintenance & -0.65 & 0.0439 \\
Labor & -0.67 & 0.0327 \\
Total Cost & -0.76 & 0.0103 \\
ASK & -0.93 & 0.0001 \\
RPK & -0.91 & 0.0002 \\
ASK-RPK & -0.88 & 0.0006 \\
PLF & -0.52 & 0.1218 \\
Profit/Loss & 0.246 & 0.4935 \\
\hline
\end{tabular}

Source: Authors, 2015.

Observing data from Table 4, a correlation can be seen between price and the other variables, except for profit/loss and PLF, since their p-value was not significant. The correlation demonstrating greatest significance is ASK, with a p-value of 0.0001 , with there being a negative correlation of -0.93 between ASK and ticket price. In this case, the theory confirms this relationship, the greater the supply of a product, the lower will be its price, and vice versa. Demand shows a behavior that opposes the theory. Table 4 shows a correlation between ticket price and demand of -0.91 , with a significance level of 0.0002 . However, in theory, the relation should be positive, as the greater the demand for products and services, the greater should be their cost price (Vasigh et al., 2008).

In the Brazilian airline industry, the relation between ticket price and supply/demand has a strong 
relationship, as demonstrated in Table 4. However, supply on its own does not convey the facts about pricing and there is inconsistency when considering demand, as it maintains a negative correlation with ticket price, when in fact this correlation should be positive. This occurs because supply affects demand constantly and vice versa, therefore, interpreting the correlation between both variables and ticket price is more coherent.

The ASK-RPK relationship reveals the lack of use of the available seats. The correlation obtained with ticket price was -0.88 , which represents a strong negative relationship. This lack of filling the available seats shows why prices are decreasing successively. Table 2 presented the variable PLF and considering the years 2011, 2012 and 2013, the PLF was 70.17\%, 72.94\% and $76.13 \%$, respectively, exhibiting idle capacity within the sector that should be better explored. More passengers can be attracted to increase the load factor and thus, decrease the idle capacity. Reductions in ticket price is an indispensable tool for achieving this and the explored data verifies this fact.

Knowing that the variable ASK-RPK has a strong correlation with ticket price becomes relevant to identify a mathematical model and, with the support of ActionR Software through the least square method, the simple linear regression model presented in Equation 1 was built.

$$
\mathrm{P}=318,88-5,97 \cdot \mathrm{A}
$$

The Equation 1 variables refer to: $\mathrm{P}$, average price of airline tickets (dependent variable) in USD; A, difference between supply and demand (ASK-RPK) in billion (independent variable).

Equation 1 shows the causal relationship between average ticket price and ASK-RPK. It is possible from this relationship to analyze the average ticket price trend in the market through the variation of supply and demand. It can be seen from this equation that for each billion ASK unused, the average ticket price tends to decrease USD 5.97. Ticket price tends to decrease in order to bring supply and demand closer together, providing an attraction of demand in order to achieve a balance between the two. A greater supply than demand would imply ticket price reduction, since unused ASK involves costs without revenue to cover them. Price tends to decrease to reach market equilibrium when supply distances itself from demand. Conversely, price tends to increase when demand grows at a greater rate than supply. Supply and demand theory suggests that the greater the ASK supply, the lower the ticket price should be, as the unused available seats represent costs with no generated revenue, and therefore, the airlines decrease tickets prices to fill the available seats (Vasigh et al., 2008).

When examining costs, a negative correlation can be seen between ticket price and fuel, maintenance and labor expenses, and total costs, being $-0.72,-0.65$, -0.67 and -0.76 , respectively. Something unusual can be observed from these values. Ticket price should be seen to increase to cover these growing costs so the correlation should be positive, however the opposite occurs. Ticket prices decreased and costs increased, thus denoting a negative correlation.

The quantity of ASK can explain the growing costs. Table 5 shows a positive and significant correlation between supply and costs. A greater supply of seats implies higher costs as the growth in supply means more availability of aircraft, consequently generating higher expenditure on fuel, maintenance and labor, among others. The supply of airline seats has grown considerably since the establishment of Brazilian Law $11.182 / 2005$, as explained by ANAC (2015). This regulation spawned policies that opened up the market to free competition, permitting airlines to adopt supply and pricing strategies according to their needs and following the market flow. The purpose was to establish a strong and competitive market bringing improvements to the Brazilian airline industry (ANAC, 2014).

Table 5. Correlation matrix (ASK x Costs)

\begin{tabular}{lll}
\hline & ASK & P-value \\
Fuel & 0.88 & 0.0006 \\
Maintenance & 0.75 & 0.0126 \\
Labor & 0.84 & 0.0024 \\
Total Costs & 0.91 & 0.0002 \\
\hline
\end{tabular}

Source: Authors, 2015

Analysis of Table 5, in comparison to the data in Table 4, demonstrates a stronger and more significant correlation between supply/demand and average ticket price, a fact that does not changes the importance of costs in the tickets price. However, it does suggest that supply and demand are the most significant variables to be analyzed when creating pricing strategies.

\section{Conclusion}

This research aimed to establish the relationship between ticket price and operating costs, supply and demand. From analysis of the researched data, it is suggested that ticket price is subtly influenced by costs, with supply and demand assuming the main role of influence due to the idle capacity within the sector, 
characterized by greater supply than demand, thus forcing the airlines to adopt lower prices and increase accessibility to the population. This scenario has resulted in successive losses over recent years for the Brazilian airline industry.

The sector has registered an improved passenger load factor. In 2011, 2012 and 2013, registered PLF values were $70.17 \%, 72.94 \%$ and $76.13 \%$, respectively. From 2004 to 2013, the load factor improved by $11.2 \%$. The market, however, is still undergoing transformation following the relatively recent introduction of the Brazilian Law 11.182/2005, which promotes greater freedom in ticket price and supply. Every year, the relationship between supply and demand is becoming more balanced. Consolidation of the market is expected to continue following the removal of barriers to market entry, consequently leading to the creation of new airlines, expansion of services to both remote domestic and international routes, and industry standardization. It will also provide new financial and statistical data, giving support to the decision-making process of managers and delivering information to investors and new incoming companies to the sector (ANAC, 2010).

This study presented a general analysis of Brazilian air transportation, intending to demonstrate how the variables supply, demand and costs are related to ticket price. Although these variables are the most representative for such, other factors should also be considered for a complete analysis, such as the study of customer expectation, flight delays and cancellations, flight schedules and connections, ticket differentiation, airline size, promotions, and the economic scenario, among others. (ANAC, 2014).

The decision-making process for airlines is complex and full of challenges. It is proposed that data analyzed by this study can be adopted in further research examining marketing and financial strategies for this sector. Marketing strategies can consider how to attract greater numbers of customers to fly and financial strategies can seek greater efficiency in cost control, all targeted on the well-being and satisfaction of aviation industry customers.

\section{Acknowledgments}

The National Council for Scientific and Technological Development (CNPq) and The State of Goiás Research Foundation (FAPEG)

\section{References}

ALAMDARI, Fariba; MORRELL, Peter. Airline labour cost reduction: post-liberalisation experience in the USA and Europe. Journal of Air Transport Management, v. 3, p. 53-66, 1997. http://dx.doi.org/10.1016/S0969-6997(97)00024-0

ANAC. Anuário do transporte aéreo: dados Estatísticos e Econômicos de 2013, 2014. Available at: < http://www2.anac.gov. br/estatistica/anuarios.asp >. Accessed: 25th November 2014.

ANAC. Planejamento Estratégico, 2010. Available at: < http:// www2.anac.gov.br/arquivos/ANAC\%20Planejamento\%20 Estrategico.pdf $>$. Accessed: 04th June 2015.

ANAC. Tarifas Aéreas Domésticas. 31. ed. (2o semestre de 2014), 2015. Available at: <http://www2.anac.gov.br/ estatistica/tarifasaereas/pdf/31-Edicao_Relatorio_de_Tarifas Aereas_Domesticas.zip >. Accessed: 16th April 2015.

DIAS, Ivan Pinto. Algumas observações sobre a margem de contribuição. Revista de Administração de Empresas. São Paulo, v. 32, n. 3, p. 36-45, 1992.

DIFIGLIO, Carmine. Oil, economic growth and strategic petroleum stocks. Energy Strategy Reviews, v. 5, p. 48-58, 2014 http://dx.doi.org/10.1016/j.esr.2014.10.004

GUJARATI, Damodar N. Basic econometrics. 4th ed. New York: The McGraw-Hill Companies, 2004.

IATA. Airline cost performance: IATA economics briefing no 5, 2006. Available at: <http:/www.iata.org/whatwedo/ Documents/economics/airline_cost_performance.pdf $>$. Accessed: 17th November 2014.

ICAO. Manual on the Regulation of International Air Transport. 2nd ed. 2004. Available at: < http://www.icao.int/Meetings/ atconf6/Documents/Doc\%209626 en.pdf>. Accessed: 17th June 2015.

KUN, Wang; XINGLI, Fan; XIAOWEN, Fu; YIRAN, Zhou. Benchmarking the performance of Chinese airlines: An investigation of productivity, yield and cost competitiveness. Journal of Air Transport Management, v. 38, p. 3-14, 2014. http://dx.doi.org/10.1016/j.jairtraman.2013.12.012

PORTAL ACTION. Correlação de Pearson, 2015. Available at: $<$ http://www.portalaction.com.br/manual-action/13-matriz-decorrelacao $>$. Accessed: 02nd June 2015.

SIEW, Lim; YONGTAO, Hong. Fuel hedging and airline operating costs. Journal of Air Transport Management, v. 36, p. 33-40, 2014. http://dx.doi.org/10.1016/j.jairtraman.2013.12.009

TAE, Hoon; CHUNYAN, Yu. Cost competitiveness of major airlines: an international comparison. Transportation Research Part A: Policy and Practice, v. 32, p. 407-422, 1998. http://dx.doi.org/10.1016/S0965-8564(98)00007-X

VASCONCELOS, Marco Antônio Sandoval de. Economia: Micro e Macro. 3. ed. São Paulo: Atlas, 2002.

VASIGH, Bijan; FLEMING, Ken; TACKER, Thomas. Introduction to air transport economics: from theory to applications. Burlington: Ashgate, 2008.

WEN-CHENG, Lin. Financial performance and customer service: An examination using activity-based costing of 38 international airlines. Journal of Air Transport Management, v. 18, p. 13-15, 2012.

ZUIDBERG, Joost. Identifying airline cost economies: An econometric analysis of the factors affecting aircraft operating costs. Journal of Air Transport Management, v. 40, p. 86-95, 2014. http://dx.doi.org/10.1016/j.jairtraman.2014.06.007 